\title{
Effects of EGFR Expression on Anti-tumor Efficacy of Vandetanib or Cediranib Combined with Radiotherapy (RT) in U87 Human Glioblastoma (GBM) Xenografts
}

\author{
P. Wachsberger \\ Thomas Jefferson University and Hospitals \\ Y. R. Lawrence \\ Thomas Jefferson University and Hospitals \\ Y. Liu \\ Thomas Jefferson University and Hospitals
}
A. P. Dicker
Thomas Jefferson University and Hospitals
Follow this and additional works at: https://jdc.jefferson.edu/bodinejournal
Part of the Oncology Commons
Let us know how access to this document benefits you

\section{Recommended Citation}

Wachsberger, P.; Lawrence, Y. R.; Liu, Y.; and Dicker, A. P. (2010) "Effects of EGFR Expression on Anti-tumor Efficacy of Vandetanib or Cediranib Combined with Radiotherapy (RT) in U87 Human Glioblastoma (GBM) Xenografts," Bodine Journal: Vol. 3 : Iss. 1 , Article 3.

DOI: https://doi.org/10.29046/TBJ.003.1.002

Available at: https://jdc.jefferson.edu/bodinejournal/vol3/iss1/3

This Article is brought to you for free and open access by the Jefferson Digital Commons. The Jefferson Digital Commons is a service of Thomas Jefferson University's Center for Teaching and Learning (CTL). The Commons is a showcase for Jefferson books and journals, peer-reviewed scholarly publications, unique historical collections from the University archives, and teaching tools. The Jefferson Digital Commons allows researchers and interested readers anywhere in the world to learn about and keep up to date with Jefferson scholarship. This article has been accepted for inclusion in Bodine Journal by an authorized administrator of the Jefferson Digital Commons. For more information, please contact: JeffersonDigitalCommons@jefferson.edu. 


\title{
Effects of EGFR Expression on Anti-tumor Efficacy of Vandetanib or Cediranib Combined with Radiotherapy (RT) in U87 Human Glioblastoma (GBM) Xenografts
}

\author{
Wachsberger, P., Lawrence, Y.R., Liu, Y., Dicker, A.P. \\ Department of Radiation Oncology, Thomas Jefferson University and Hospitals, Philadelphia, PA
}

\section{Introduction}

Vandetanib is a receptor tyrosine kinase inhibitor (RTKI) with activity against vascular endothelial growth factor receptor-2 (VEGFR-2) and epidermal growth factor receptor (EGFR). Cediranib is a highly potent VEGF RTKI that inhibits all three VEGF receptors. In this study we investigated the effect of exogenous overexpression of EGFR on sensitivity of human GBM U87 xenografts to vandetanib or cediranib, alone or in combination with RT.

\section{Methods}

Animal and tumor model: Human U87 GBM cells, stably transfected with EGFR (U87 EGFR) or empty vector (U87 vector), were injected subcutaneously into the right hind limbs of athymic NCR NUM mice. Drug Administration: Vandetanib was dosed at $50 \mathrm{mg} / \mathrm{kg}$ daily for two weeks starting on Day 0. Cediranib was dosed at $3 \mathrm{mg} / \mathrm{kg}$ daily for two weeks starting on Day 0. RT was administered as three daily fractions of $5 \mathrm{~Gy}$ on Days 0,1 and 2. On the days that RT and vandetanib/cediranib were both given, drugs preceded RT by $1 / 2$ hour. Statistical Analysis: Mixed-effects linear regression was used to model tumor volume as a function of time and treatment Analysis of VEGF levels in U87 EGFR or U87 vector cells in culture: Cells were irradiated at doses between 0-10 Gy and incubated in the presence or absence of vandetanib (0-10 microM) or cediranib (0-10 nanoM) for 48 hrs. VEGF was assayed from culture supernatants using a commercially available human VEGF immunoassay kit (R\&D Systems, Minneapolis, MN).

\section{Results}

Exogenous over-expression of EGFR altered tumor doubling time (T2x (days)) in U87 xenografts (2.70 for U87 EGFR vs. 4.41 for U87 vector). In U87 EGFR xenografts, single agent RT, vandetanib or cediranib significantly increased tumor doubling time (T2x (days)) when compared to control (4.79 for RT; 6.32 for vandetanib and 5.00 for AZD vs. 2.70 for control). In U87 vector xenografts, RT but not drugs significantly increased T2x (6.56 for RT vs. 4.41 for control). In U87 EGFR xenografts, the combination of RT with vandetanib but not RT with cediranib was significantly better than RT alone
$(\mathrm{T} 2 \mathrm{x}=10.37$ for $\mathrm{RT}+$ vandetanib vs.4.79 for $\mathrm{RT}$ alone $(\mathrm{p}<0.001)$ implying radiosensitization. Neither drug radiosensitized U87-vector xenografts. In cell culture, radiation induced VEGF secretion from both U87-EGFR and U87-vector cells in a dose-dependent manner. Vandetanib (10 microM), but not cediranib suppressed radiationinduced VEGF release in U87-EGFR cells and to a lesser extent, in U87-vector cells.

\section{Conclusion}

These data demonstrate that exogenous EGFR expression in U87 human GBM xenografts appears to induce greater sensitivity to the combination of RT + vandetanib compared with RT + cediranib. This observation suggests that EGFR signaling may have a direct influence on U87 tumor radiosensitivity in vivo, or an indirect effect on the tumor vasculature or microenvironment, perhaps through upregulation of tumor derived growth factors such as VEGF.

This work was supported by a grant from AstraZeneca Pharmaceuticals and a Radiation Therapy Oncology Group TRP seed grant. 